\title{
A jászkeszeg és a ragadozó őn neveinek történeti-etimológiai vizsgálata
}

jász J. Leuciscus idus (MoH. 70). Szálkás édesvízi hal. Háta sötétszürke, úszói közül a párosak és a farok alatti szép élénkvörös színü. Hazánkban legfeljebb 4 kilósra nő meg.

1549: jaz kezeg 'Phoxinus laevis' (OklSz. 427), 1590: iaz kezeg 'ua.' (SzikszF.

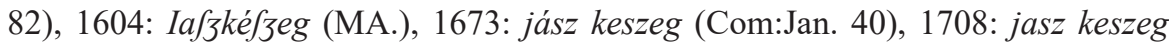
'Thymallus', 1729: jászkeszeg 'Idus melanotus' (HalK. 798), 1791: jász-kejzegek (Dugonics 1: 202), 1801: jászkeszeg 'Cyprinus orfus', jász 'Cyprinus jeses' (Term. Hist. 268), 1830: jász 'Idus melanotus' (Reisinger 62), 1833: jászkeszeg, jászponty 'Cyprinus jeses' (Dankowsky 513), 1846: jász keszeg 'Cyprinus orfus' (ÁM. 821), 1868: jászkeszeg (Kriesch 72), 1882: jász 'Leuciscus vulgaris' (Chyzer 9), 1887: jászkeszeg 'Idus melanotus' (HalK. 764). A népnyelvben ÚMTsz. 2: 1140: gyászkeszeg, jászkeszeg, jáz, jác, jász-keszeg|Kovács 64:jáz, jázikó, jászi 'Leuciscus idus'|Kassai 3: 69: jáz|SzegSz. 1: 654: jászkeszeg 'Squalius dobula'. A gyászkeszeg népetimológiás átalakítás eredménye. Kniezsának az tűnik fel, hogy míg a jász a MTsz.-ban csak önállóan szerepel, a szótörténet forrásaiban csak összetételben (SzlJsz. 229). Ez azonban nincs így, elég példát látunk fent az ellenkezőjére is.

A magyar szó forrásaként elsősorban a szbhv. jâz és a szln. jez (TESz. 2: 264) jöhet számításba. További szláv megfelelöi: szlk. jalec, cs. jalec, jasek, jezůvě, le. jaź (FB.), jaziec, jazica, óle. jazic, jazice (RF. 51), szlk. jas (SzlJsz. 230), hv., szln. jez, fehéror. язь, ukr. в 'язь, szerb јаз (W.), оr. язь 'ua.' (EL.; 1793: jasch, jafz [Allg. Pol-Lex. 1: 1361]). A kárpukr. jáz-gol, jaz-keszeg 'Leuciscus leuciscus' (Владыков 230) viszontkölcsönzés a magyarból. Átkerült a szláv szó a németbe is; vö. jaz' (1607: RF. 52), nyelvjárási Jase, Jesen, Jesenitz (FB.), Jese 'ua.' (W.; 1860: Jese 'ua.' [Univ.Lex. 9: 336]). A német nyelvjárásokban adatolható a név Jäse, Gäse, Göse, Gesenitz, Gisitzer (FB.) alakváltozata is Poroszországból. A ném. Jese (FB.; 1557: Jesen [Hist.An. 170a]) alakváltozat a német nyelvterületen Pomeránia és Csehország között használatos, a jász cs. jesen, jelec jesen (FB.) nevének átvétele. A cseh terminust a szlovák is átvette; vö. jaseň, jasek, jesen 'ua.' (Ferianc 35). A ném. Jese halnév annyira elterjedt volt, hogy a jász egyik latin szaknyelvi nevében is felbukkant; vö. Cyprinus jeses (Linné 1758: Syst.Nat. 1: 324).

A tény, hogy ez a halnév csaknem mindegyik szláv nyelvben megvan, és egybehangzóan a jászt jelöli, arra enged következtetni, hogy egyrészt igen régi halnév, másrészt a halfaj eurázsiai általános elterjedtsége is biztosnak tekinthető. Ennek megfelelően írja G. V. Nikolskij: „язь [...] воды Европы от Рейна на Восток о Сибирь до Колымы” (Никольский 197). A hal nevét ősszláv szónak tartja Machek (ZSIPh. 19: 67) és Vasmer (REWb. 3: 486) is.

A jász köznyelvi neve az ónkeszeg (MoH. 70; 1622: ua. [Unger 68], 1794: ónhal 'ua.' [Grossinger 123], 1887: ónkeszeg, ónos jász 'Idus melanotus' [HalK. 764], 1904: ónos jász [Prem.gimn. 27[). Ezt az elnevezését a színéről kapta. A jász háta ívás idején ugyanis különösen szürke. Tudományos ónos jász neve is a szürke fémmel van kapcsolatban. A jász színére utaló elnevezés megvan a vogulban is; vö. 


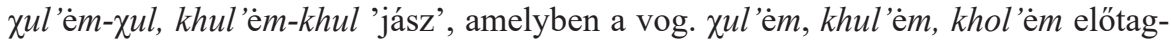
nak 'hamu' a jelentése (WogWb. 121b). A halnév jelentése tehát 'hamuhal, szürke hal'. Hasonló a ném. Schwarznerfling 'fekete jász' (VN. 6360), valamint a cs. jalec tmavy, szlk. jalec tmavý (FB.) a 'sötét' faji jelzővel. Ugyanez a névadási szemlélet háttere nyelvjárási ÚMTsz. 2: 1140: gyászkeszeg, gyâc 'jász' névnek, amely népetimológiás átalakítás eredménye.

További társneve az orfa (MoH. 70; 1884: arany orfa [Vadl. 29: 393], 1897: orfa ivadék [Landgráf 436], 1939: Idus melanotus var orfa [Hal. 1-2: 11]), amely német jövevényszavunk. A Grimm testvérek szótárában Cyprinus orfus a hal latin elnevezése. A német szó görög-latin eredetü, az ókori orphus halnév a végső forrás (Plinius egy pirosas színü tengeri halat jelölt vele). A németben igen régröl adatolható: ófn. orvo, kfn. orve, orfe (ÖF. 56 (5/6): 149), azután Orfe, Orf, Örfling (VN. 6360), Urf, Urs 'ua.' (FB.; 1575: Orff [Fischb. 167], 1613: ua. [Aldrovandi 605], 1670: Orff, Urff 'Orfus' [Gesnerus red. 4: 169], 1716: Orfen [Ausf.B. 41], 1757: orf [Estor 1: 941], 1774: Urf, Orfe 'Cyprinus orfus' [Müller 4: 393], 1782: Orfen [Rössig 2,1: 559], 1790: Orf, Urf [HbDT. 165]), 1793: Orfe, Orf, Urf 'Cyprinus orfus' [Allg.Pol-Lex. 1: 1361], 1839: Orfe Urfe [Gmelin 365], 1864: Orfe 'Idus melanotus' [Jäckel 63]).

Természetesen idetartozik az ang. orfe 'ua.' (FB.) és az or. orfa, le. urfa, orfa 'ua.' (RF. 54), valamint a régröl adatolható holl. orf (1776: ua. [Müller 4: 393], 1793: ua. [Allg.Pol-Lex. 1: 1366]), a fr. orfe, orphe 'ua.' (VN. 6360; 1793: orfe [Allg. Pol-Lex. 1: 1366], 1839: ua. 'Cyprinus orfus' [Gmelin 365]) halnév is. Használatos a színnevekkel (piros, fehér, ezüst) alkotott fr. ide rouge, ném. Rotorfe (EL.; 1757: roter orf [Estor 1: 941]), a weißer orf (1757: weifer orf [uo.]), valamint az ang. silver orfe (FB.) is. A ném. Goldorfe, unechter Goldfisch, Goldnerfling, fr. ide dorée, ang. golden orfe (uo.), azaz 'hamis aranyhal, aranyjász' terminusok a jász egy aranysárga színváltozatának a nevei, amelyet előszeretettel díszhalként tenyésztenek.

A nyerfli (MoH. 59; 1887: ua. [HalK. 815], 1904: ua. [Vutskits 15], 1919: ua. [Unger 68], népnyelvi MTsz. 1: 1542: ua. | Kovács 19: jerfli | DLw. 26: nyerfling) halnevünk a ném. Nerfling 'jász' (FB.) átvétele. A régi német szakirodalomban a jász Nörfling, korábban Örfling és Orfe, Urf neve, továbbá számos alakváltozat olvasható. A -ling végződés igen gyakori a délnémet nyelvterületen (például halnevekben Äschling < Äsche, Näsling < Nase, Sichling, Gründling, Bitterling stb.). A ném. Nerfling régröl adatolható, 1558: nerfling [Hist.An. 1266], 1604: ua. [Ges.Med. 9], 1682: Nerfling [Hohberg 2: 484], 1765: ua. [Icht.Bor. 46], 1792: ua. [Bechftein 766], 1793: ua. 'Cyprinus idus' [Allg.Pol.-Lex. 1: 1361], 1839: ua. 'Cyprinus orfus' [Gmelin 365], 1863: ua. [Siebold 176], 1864: ua. 'Idus melanotus' [Jäckel 63]). A régi angol szakirodalomban is említik ezt a terminust, 1686: nerfling 'Orfus germanorum' (Hist.Pisc. 24). A német halnév alakváltozata a Nörfling (1575: Norffling [Fischb. 167], 1613: Norfling [Aldrovandi 605], 1670: Norffling 'Orfus' [Gesnerus red. 4: 169], 1682: Norflingen [Hohberg 2: 17], Norfling [uo. 505], 1757: nor fling [Estor 1: 941], 1782: Norflinge [Rössig 2,1: 559], 1790: Norfling (HbDT. 165), 1793: Oerfling, Nörfling 'Cyprinus orfus' [Allg.Pol.-Lex. 1: 1361]). Ez a német halnév a jász fenti elnevezésével függ össze, a Nerfling, Nörfling ugyanis az Orfe, Örfling 'ua.' nevekből származik a határozatlan névelő $n$ elemének a szó elé ragasztásá- 
val. A ném. Erfle, Erfel (1670: Erflin 'Orfus' [Gesnerus red. 4: 169], 1765: Erfling 'Cyprinus idus' [Icht.Bor. 46], 1790: Erffle [HbDT. 165], 1793: Aerfel 'Cyprinus orfus' [Allg.Pol-Lex. 1: 1361]) a ném. Erfling (1793: uo.) rövidebb formája, amikor a Nerfling névben a szókezdő hangot elnyelik.

Több más halfaj nevével is jelölik a jászt, ezek a téves terminusok külső jellegzetességeikben hasonlító fajok neveivel jöttek létre. Például 1882: csobak 'Leuciscus idus' (Chyzer 9), 1884: csabak (Nyr. 13: 554); ÚMTsz. 1: 732: csabak 'keszeghez hasonló piros szárnyú, hosszúkás, szálkás hal'. A csabak a magyar írásbeliségben viszonylag kései fölbukkanású halnevünk, török jövevényszó, közelebbről kun-besenyő eredetü (TESz. 1: 463). Az or. cebák, cabák, ukr. cebak (REWb. 3: 307) szintén török eredetü, a szlovákba esetleg a magyaron keresztül került a név. Legközelebbi rokon nyelvünkben, a vogulban is megvan; vö. vog. sapak 'cebak' (RLw. 248), ott orosz eredetü jövevényszó. A zürjén bad'-kor-tšeri 'Cyprinus idus' (NyK. 49: 49) névnek tulajdonképpen 'füzfa-levél-hal' a jelentése. Ma az őn a balin neve, ám korábban a jászt is emlegették ezen a néven; 1801: ön 'jász' (Term.Hist. 268), 1865: ua. (Hunfalvy 736), ez a halnevünk finnugor kori örökség. A tengeri ponty (Kovács 64) szigetközi elnevezés, a jász ném. Seekarpen, Seekarpfen (FB.) nevének mintájára talán a pontyfélék családjába tartozó jászról helytelenül úgy képzelték, hogy a tengerből úszik föl a Dunán. Ugyanott használatos nádiponty (Kovács 64) neve is, mert „,szereti a föhennyet s a nádasokat”. A szélhal tulajdonképpen a küsz 'Alburnus alburnus' (MoH. 77) neve, de korábban a jászt is ismerték ilyen néven; vö. 1801: szélhal 'Cyprinus idus' (Term.Hist. 268), 1846: ua. (ÁM. 800), 1863: feketehátú szélhal 'ua.' (Heck. 206). Tiszafüred környékén kövesdi potyka (Nyr. 1999: 210), mert pontyként kérdezték az árát a mezőkövesdi piacon.

Linné a latin szaknyelvi Cyprinus idus binóment adta a fajnak 1758-ban (Syst.Nat. 1: 324). Szinonim neve a szaknyelvben Cyprinus idbarus, Cyprinus orfus és Cyprinus jeses (uo.). Herman Ottónál 1887-ben a jászkeszeg latin szaknyelvi neveként az Idus melanotus (HalK. 764) binómen szerepel, ennek megfelelöje a fr. ide mélanote 'ua.' (FB.). A ma érvényes Leuciscus idus latin binómenben a Leuciscus genusnév a gör. leukósz 'fehér' szóból való, a hal ezüstös, világos színére utal. A jász az úgynevezett „fehérhalak” közé tartozik. Mai gör. leukiszkosz-tsziróni (uo.) nevének is ez az alapja. A lat. idus fajnevet Linné adta, nem világos azonban, hogy miért. Eredete mindenesetre az az idus szó, amely a rómaiak naptárában a 13. napot, illetve a Martius, Maius, Quintilis és Octobris hónapokban a 15. napot jelentette. A jász egyik társneve is az ang., fr. ide (uo.; 1793: ua. [Allg.Pol-Lex. 1: 1361], 1839: l'ide [Gmelin 364]), ol. ido, sv. id (FB.).

Társneve még a ném. Aland, Alander, Alant, Alat (FB.; 1624: Alander, Aland [Icht.Nom. 42], 1639: Aland [Micraelius 6: 384], 1757: alet [Estor 1: 941], 1798: Aland 'Cyprinus jeses' [Donndorff 736], 1860: ua. [Univ.Lex. 9: 336], 1863: ua. 'Idus melanotus' [Siebold 176]). Megvan más nyelvben is; vö. lett alants 'ua.' (FB.). A ném. Elize, Elsrode, Elte, Ertel (uo.) társnevét korábban szintén több más halfajra is értették. A ném. Gängling, Gänzling, Gendling, Genge (uo.) a ném. gängeln 'járni tanulni' igéből származik, és a jász vándorlására utal. A jász ném. Kühling (uo.; 1792: Kühling [Bechftein 766], 1793: Kühling [Allg.Pol-Lex. 1: 1361], 1839: 
Kueling [Gmelin 364], 1840: Kühling, Keuling [Reichenbach 85], 1860: Kühling, Keuling 'Cyprinus idus' [Univ.Lex. 9: 336]) neve több halfajt is jelöl. A ném. Kaule szóból származik, amely a Keule, Kuhle rokona, és a halak nagy fejére utal. Köznyelvi neve még a németben a Häwt, Helm, Juntling, Kilps, Lachsapparre, Mähne, Münne, Nennen, Tabarre, Tabelle, Tapar, Topar (FB.). További társneve a ném. Frauenfisch (1839: Frauenfifch [Gmelin 365], 1840: ua. [Reichenbach 85]) és a fr. gardon ruff (1840: Reichenbach 85), norv. vederbuk, or. подъязык, sp. cacho, cachoelo, cachuelo (FB.), továbbá a dán rimte, litv. paprastoji meknè,blg. мъздpyza (W.), dán emde, ejbygedde, strandkarpe, holl. winde, tatár bertas (1793: Allg.Pol.Lex. 1: 1366), upta (uo. 1361), baskír optu (1793: uo.). Felső-Ausztriában Seider (FB.) néven is ismerik.

A jász elsősorban a síkvidéki folyók lakója, erre utal cs. jesen nižinný (uo.), azaz 'alföldi jász', illetve ném. Stromkarpfen (uo.), vagyis 'folyamiponty' elnevezése. A cs. ryba májová (uo.) nevének 'májusi hal', a ném. Rohrkarpfen (uo.) nevének 'nádponty, csőponty' a jelentése. A románban lugojanel (FB.), továbbá văduviţă (uo.; 1909: văduviţă, văduvioară [Antipa 174]), a Duna-deltában joltomeasa és daviţa (ua.). A török nyelvekben a csuvas ănmă, tatár onmbl, kazah ақ қ̧аŭран (W.) neveken ismert. Az or. язь золотой (FB.) nevének 'arany jász' a jelentése, a portugálban az ezüst jelzővel alkottak nevet a fajnak; vö. escalo-prateado (uo.). Az angolban Orfus germanorum, azaz 'német jász' értelmezéssel régröl adatolható rudde (1686: Hist. Pisc. 24) társneve.

Az uráli nyelvek területének vizeiben is honos hal a jász, ezekben a nyelvekben is megvan természetesen a neve; vö. fi. säyne, észt säinas (FB.), vepsze säunaz, zürj.

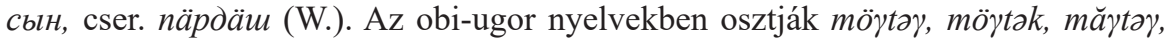

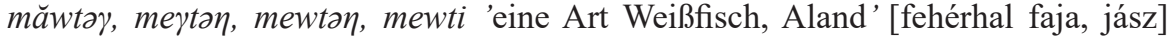
(DEWOS 917) és vogul moutèk 'kleiner Aland' [kis jász] (WogWb. 318a), amelyekben az osztják $-\gamma,-\eta$, - $i$ és a vogul $-k$ képzők. Vö. zürjén mik 'Weißfisch' [fehérhal], mek 'Barbe' [márna] és cseremisz müktə, müktö 'Gründling' [fenékjáró küllő], müktü 'Ukelei' [küsz] (UEW. 295). Az osztják halnév mehdem 'Squalius mehdem Warp.' alakban bekerült a nemzetközi zoológiai taxonómiába. Jövevényszóként megvan az oroszban is; vö. or. megden, megdüm 'Leuciscus' (REWb. 2: 110), megdüm 'Leuciscus leuciscus baicalensis' (Никольский 618), az átadó nyelv Kálmán szerint (NyK. 53: 159) az egyik délnyugati osztják nyelvjárás, Steinitz szerint (ZSIPh. 5: 505) az Irtis-nyelvjárás. 'Kis jász' a jelentése az osztják ńălək (DEWOS 1053) halnévnek, amely etimológiailag a vogul ńalk és jurákszamojéd ńilok, ńōl'oku

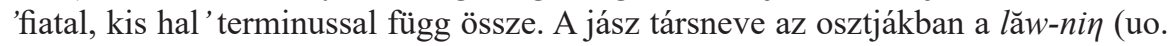
862), a kis jászé a məl'ək (uo. 931), a különösen nagy jászé pedig az okri (uo. 47). A jász társneve a vogulban az art, arèt, oårt, ärkèt (WogWb. 50a), illetve a måš (uo.), a nagy jászé måš-oårt (uo.), a kis jászé måš-pū (uo. 438b), azaz ’jász fiú'. További neve az obi-ugor nyelvekben a vogul sama (1793: Allg.Pol-Lex. 1: 1366), valamint

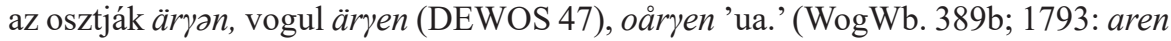

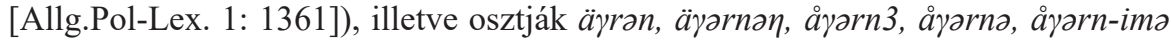

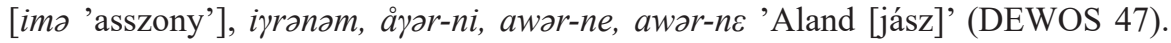
A szóvégi - $n$ kicsinyítőképző, a -ni, -ne 'nő, asszony' szót pedig igen gyakran teszik állatnevek mögé, mégpedig a kisebb termetü állatok nevéhez. 
Az őn szálkás húsú édesvízi hal. Európa valamennyi nagyobb folyó-, illetve állóvizében megtalálható. Kis halakra, elsősorban küszökre vadászik, felfelé nyíló szájával a felső vízrétegekben keresi táplálékát.

őn, ragadozó őn J. Aspius aspius (MoH. 81). Hazánkban is honos minden jelentősebb folyóban és tóban. Noha 6-7 kg-os tömeget is elér, és húsának - szakszerüen elkészítve - igen jó az íze, a fogyasztók általában nem értékelik sokra szálkássága miatt.

Az őn a magyarban sokáig inkább csak nyelvjárásokban előforduló halnév volt, a 19. században került be a szakirodalom nyelvébe. Ma állattani szakszó. Ugyanakkor igen régi halnevünk, 1211: euuen 'Aspius rapax' (OklSz. 724), 1794: ön 'Alburnus' (Grossinger 221), 1801: ön 'jász' (Term.Hist. 268), 1830: ön 'balin' (Reisinger 63), 1838: őny (Tsz. 153), 1846: ön 'jász' (ÁM. 800), 1863: ragadozó őn (Heck. 205), 1865: ua. és ön 'jász' (Hunfalvy 736), 1868: őn 'ua.' (Kriesch 33), 1882: ragadozó ön 'ua.' (Chyzer 10), 1884: ön, őnkeszeg 'ua.', őn 'Aspius rapax' (Nyr. 13: 553), 1902: ragadozó ön 'ua.' (Jankó 311), 1930: ua. (BrehmL. 14: 231). A nyelvjárásokban ÚMTsz. 1: 798: őn | MTsz. 2: 37: őn 'keszeg', ünhal 'Alburnus lucidus', őny-hal, ün-hal 'paduc', őn, őny, őnyhal, ün-hal, őnhal $\mid \mathrm{MoH}$. 81: őnborjú, önkeszeg, ragadozó ön, táncos ön | HalK. 816: on, önkeszeg, önhal, ün-hal, önyhal | Gyurkó 164: önhal).

Ez a halnevünk finnugor kori örökség, vö. fi. säynäs, säynäjä, säynät, säynää, säynävä 'Leuciscus idus' (SKES. 1177a), karj. süneh, lív säünäg, säünäg, vepsz. säng 'jász', észt säinas, säina, N. seinas, seina, säänäs 'ua' (EEWb. 9: 2982), lp. seuna, seuna, siuna, votj. son, son-corig 'ua.', lp. sivn 'domolykó', zürj. sin 'ua.', mordvin senej, seńi, señä 'halfaj' (Mäger). A mordvin $-j$, fi. $-s$, -jä, észt $-m,-s$ denominális névszóképzők. Az eredeti jelentés Leuciscus-faj lehetett. Föltünő az alapalak távoli finnugor nyelvekben való megléte azonos, 'jászhal' jelentéssel. Az etimológiát már viszonylag régen fölállították (Wichmann: MNy. 4: 77; Setälä: FUF. 2: 258; Itkonen: uo. 31: 270). A mordvin senej, seńi, seńä halnév átkerült az oroszba; vö. or. singá 'keszegféle' Szaratov környékén és sengá 'ua.' a Don vidékén (REWb. 2: 610 és 627). Manfred Bausch viszont északorosz szónak tartja az or. senga halnevet, és átadónak a keleti-tengeri finn nyelveket jelöli meg (Bausch 24). Hibás Collinder (FUV. 127) jelentésmegadása (ugyanígy SKES. 1177a, illetve EEWb. 9: 2982), a magyar ôn ma nem jászt, hanem balint (Aspius aspius) jelent. Nem tartoznak ide a Sebestyén Irén idézte bizonytalan obi-ugor szóösszetételek (NyK. 49: 37) második szótagjai, mert

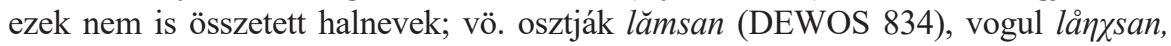

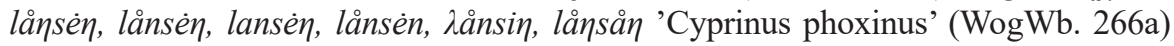
a szókezdőnek vélt obi-ugor $s$ - miatt. De az egyeztetésnek jelentéstani problémája is fölmerül.

A binominális nómenklatúra hivatalos elnevezése ragadozó őn $(\mathrm{MoH} .81 ; 1863$ : ua. [Heck. 205], 1865: ua. [Hunfalvy 736], 1868: ua. [Kriesch 67], 1882: ua. [Chyzer 10], 1887: ua. [HalK. 823], 1930: ua. 'Aspius rapax' [BrehmL. 14: 231]), a faji jelző az őn rablóhal voltára utal. Az unhal, ünhal (VN. 391; 1887: ünhal 'Alburnus alburnus' (HalK. 837; Unger 71: ua.) terminus minden bizonnyal összefügg az ön 'Aspius aspius' halnévvel, a balin vagy őn - ragadozó volta ellenére is - testalkatában föltünően hasonlít az un-, vagy ünhalra, azaz a küszre. 
A gyakori hal számos társnéven ismert a népnyelvben. Ilyen a táncos őn $(\mathrm{MoH}$. 81; Unger 70: ua.) is, a táncos faji jelző arra utal, hogy ez a ragadozó hal a zsákmányát üldözve nagy loccsanásokkal rabol a víz színén. A ragadozó küsz (1884: ua. 'Aspius rapax' [Nyr. 13: 553]; HalK. 823: ua.) a pontyfélékhez tartozó, de ragadozó halnak, a balinnak a más, de alakjára nézve igen hasonló halnak a nevével alkotott elnevezése. A régi forrásokban szerepel ragadozó pontyként (uo.) is. A nagy szélhal (MoH. 81; 1887: ua. [HalK. 814]) az Erdővidéken, az Olt mentén használatos halnév a küszre nagyon hasonlító, de ragadozó balinnak a neve. A kis termetü küszt szélhalnak hívják, a több kilósra megnövő balint pedig nagy szélhalnak. Hasonneve a MTsz. 2: 522: szellökeszeg, 2: 517: szélkeszeg, szélhajtó keszeg 'Aspius rapax'. A tolvaj-hal (Földr.Közl. 40: 171) al-dunai elnevezés a balin rablására (a táplálékául szolgáló kis halak zsákmányul ejtésére) vonatkozik, akárcsak cs. bolen dravý (FB.), azaz 'fosztogató balin' elnevezése. Hasonló a vadászkeszeg (MoH. 81; 1838: ua. [Tsz. 203], 1884: ua. [Nyr. 13: 554], 1887: ua. [HalK. 837], 1930: ua. [BrehmL. 14: 231; MTsz. 2: 890: ua. | SzegSz. 1: 734: ua.), valamint a fenekeszeg (MoH. 81; 1887: ua. [HalK. 785]) társneve. A pontyfélék családjába tartozó hal ragadozó volta alapján kapta ezeket a neveit, akárcsak ro. peste-lup (FB.), azaz 'farkashal' elnevezését. A paripakeszeg (Kovács 60) szigetközi társneve. A névadási szemlélet háttere az, hogy „,nyargal a víz hátán”, „lovagull a vizen” (uo.). Ez pontosabban azt jelenti, hogy a balin ragadozóként a kis halakat a víztükör felszínén üldözve ejti zsákmányul.

Villámgyorsan csap zsákmányára izmos, karcsú testével, a ragadozó hal a nyílkeszeg (MoH. 81; 1887: ua. [HalK. 815], 1930: ua. [BrehmL. 14: 231]) köznyelvi nevére gyorsaságával, szélsebes úszásával szolgált rá. A németben is Pfeilfisch (1798: ua. [Adelung 3: 1585]), azaz 'nyílhal'. Hasonneve, a villámkeszeg (MoH. 81) a víz színén raboló gyors balin találó népi elnevezése. A vízenjáró hal (uo.) a táplálékául szolgáló kis halakat üldöző, a víz felszínén raboló ragadozó találó neve, 1. még vizikeszeg (Halh. 53) nevét is. A kapókeszeg (MoH. 81; ÚMTsz. 3: 91: kapóhal, kapó-hal 'ua.', 3: 92: ua. 'kis halakkal táplálkozó keszeg'| MTsz. 1: 1044: ua. 'Aspius rapax' | OrmSz 298: kapkodó keszeg) társnevére szintén ragadozó volta a magyarázat és az, hogy ennek ellenére a zoológiai besorolás szerint a keszegfélékhez tartozik. Ragadozó halként kapta holl. roofblei (W.) nevét a rabló előtaggal, a törökben szintén erre utal koca a ğg baliğg (uo.), azaz 'nagyszájú hal' elnevezése. És szintén ez az alapja ném. Raubalet, Fraßalet (1575: Röubalet, Fraffalet [Fischb. 170a], 1603: ua. [Schwenkfeld 423], 1670: Raubalet, Fra/3alet 'Rapax' [Gesnerus red. 4: 173], 1790: Raubalet 'Cyprinus rapax' [HbDT. 164], 1792: ua. [Bechftein 769], 1793: Rabalet, Frassalet 'Cyprinus afpius' [Allg.Pol-Lex. 1: 1355], 1798: ua. [Donndorff 740]), azaz 'rablódomolykó, illetve zabálódomolykó' elnevezésének. Mint Gessner írja 1575-ben a halról: ,,seer rỏubig und fråssig”, azaz nagyon rabló és zabáló.

A baksa (VN. 1271; 1819: baksa [Tud.Gyüjt. 8: 17], 1884: ua. [Nyr. 13: 553], 1887: ua. [HalK. 763]; ÚMTsz. 1: 321: baksa 'önhal' | Dankó 422: ua.) szük

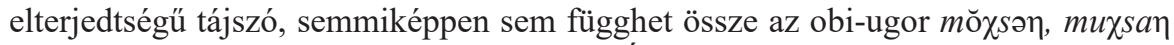
'Coregonus muksun' halnévvel, Munkácsi (ÁKE. 181) magyarázatával már Asbóth (NyK. 33: 103) szembeszállt. A torzsáskeszeg (MoH. 81; 1884: ua. [Nyr. 13: 553], 1887: ua. [HalK. 835]; MTsz. 2: 767: ua.) társnevében a torzsa a levágott nád föld- 
ben maradt szára. Nem világos, hogy a balint miért hívják így. A csereőn $(\mathrm{MoH} .81$; ÚMTsz. 1: 798: ua. 'vörhenyes színủ Aspius rapax'| Unger 64) a Balatonnál használatos, talán színváltozatra utal ez a név.

Ezüstös, igen világos színe az alapja fehérhal (Jankó 311: fejérhal 'ragadozó ön' | ÚMTsz. 2: 309: ua.) elnevezésének, akárcsak a fehérpénzü, fehérhéjjas (1902: Jankó 311), illetve az ezüstös balin (1904: ezüstös bálin [Prem.gimn. 24]) nevének. A szlávban is van az őnnek a világos testére utaló neve, az ukr. bilyzna, bilyna, bílest, biljúha és a le. bielzna, bielezna (SNPol. 2: 94) a *běl- 'fehér' szóval keletkezett. További köznyelvi neve a vezérhal, vezérőn (MoH. 81; 1887: ua. [HalK. 840], 1902: vezérkeszeg [Jankó 311]; MTsz. 2: 983: ua. „legelöl jár”| SzegSz. 2: 667: ua. „az ívás idején legelöl járó”| Tiles: vezérkeszeg 'ragadozó őn'| Viski 51: ua. ,aki vezeti a többit”| Gyurkó 164: vezérhal 'ua.') név magyarázatát a tájszógyüjtemények jelentésmegadásai alapján következtethetjük ki. A nagypénteki hal (MoH. 81; 1887: ua. [HalK 814]; MTsz. 1: 505: ua.) neve minden bizonnyal a böjti elöírásokkal függ össze, a hal különösen fontos eledel volt böjti időszakban.

Igen elterjedt a ragadozó őn balin $(\mathrm{MoH} .81)$ társneve. Szintén régről adatolható halnév, 1395 k: balyn hal 'ua.' (BesztSzj. 304), 1405 k: balin (SchlSzj. 803), 1435k: balen (SoprSzj. 143), 1570: bwlin (TermTudKözl. 26: 491), 1652: polind (SzlJsz. 74), 1794: balind (Grossinger 223), 1801: balin 'Cyprinus ballerus' (Term.Hist. 269), 1830: ua. (Reisinger 83), 1833: bajin, bőjin, bójin-hal (Kassai 1: 245), 1856: baliny (Bielz 175), 1863: balind 'Blicca argyroleuca' (Heck. 204), 1884: balinkeszeg 'Cyprinus ballerus' (Nyr. 13: 553), 1902: balin 'Aspius rapax' (Jankó 311), 1930: ua. 'Aspius aspius' (BrehmL. 14: 231). A nyelvjárásokban ÚMTsz. 1: 325: balin, balind, bálind, ballin, boli | uo. 326: balinkeszeg, bálintkeszeg, bálló keszék, bál | Hal. 33: 50: balint, bálint, polind, pólind | HalK. 772: boin, bolyin |SzegSz. 1: 106: bálinthal, ballin. Némelyik alak, mint például a bálint, népetimológiás módosulással jött létre.

A magyar halnév valószínűleg különböző forrásokból való többszörös átvétellel. A legrégibb változat, a balin a szlovákból, esetleg a horvátból származhatott; vö: cs., le., szerb, szlk., szln. bolen (FB.), ruszin балинд, bosnyák, hv. bolen (W.), kárpátukr. bolin, bolen 'ua.' (Владыков 226). A felsorolt szláv szavak az or. belizna 'Aspius aspius', ukr. білизна (W.), bilyna, biljúha 'ua.', le. bielizna 'ua.' (RF. 68) halnevekkel függenek össze. Már Peter Simon Pallas utal ezen halnevek felsorolásánál („Inter pisces Petropoli venum portatos eundem sub nomine Bjelaja ryba inveni”) a halnak a színére: „,color argento fuscus, vix aureolo passim intermicante, subtus albo subargentus" (Zoogr.R. 314). A nevek a běl 'fehér' jelzőhöz tartoznak, az igen világos testszínre utalnak. Volt is az őnnek Leuciscus aspius (Linné 1758) latin szaknyelvi neve, a Leuciscus nemi név a gör. leykiszkosz 'fehér hal' névből származik (<leukósz 'fehér'). A magyarból valók - viszontkölcsönzéssel - a következő szláv alakok: szlk. balin, balind, bojin, balyn (Ferianc 40), kárpátukr. balind (Владыков 55), szbhv. balin (RSzK. 1:272), bain (uo. 1: 245). Kniezsa (SzJsz. 74) Beke ötletét (Hal. 33: 50) ismétli, amely szerint a szláv szó a harcsa osztrák-német Wallen 'Silurus glanis, Cyprinus ballerus' átvétele volna. A német szó helyesen Waller, de az etimológia egyébként sem vehető komolyan. 
Az őn/balin fajnak Linné a latin szaknyelvi Cyprinus aspius binóment adta 1758-ban (Syst.Nat. 1: 325). Ma érvényes latin neve az Aspius aspius. A faj számos idegen nyelvi elnevezése a latin aspius terminus alapján keletkezett; vö. ang. dán, sv., norv. asp, sp. aspio, port. áspio, blg. rasper, razper (FB.), ol. aspio (W.), sv. asp (1793: afp [Allg.Pol.-Lex. 1: 1356]), fr. aspe (1793: afpe [uo.], 1798: aspe [Donndorff 740], 1839: l'aspe 'Cyprinus aspius' [Gmelin 369], 1842: aspe 'Aspius' [Selys-Longchamps 214], 1931: ua. 'Aspius rapax' [Pellegrin 334]).

Említik a németben 'kemény-, illetve vastagfej', azaz Hartkopf és Dickkopf (FB.; 1790: Dickkopf 'Cyprinus rapax' [HbDT. 164]), valamint Mulbe, Mülbe, Mülpe (FB.; 1787: Mulbe 'Cyprinus aspius' [Nau 95], 1863: ua. [Siebold 169], 1869: ua. [Brehm 5: 667], 1884: Mülpe 'Aspius rapax' [BrehmsT. 8/2: 288]) néven is. Köznyelvi neve még a ném. Ritter, Rombalet (FB.), Rotschiedel (uo.; 1884: ua. 'Aspius rapax' [BrehmsT. 8/2: 288]), Mäusebeißer (1884: ua. [uo.], azaz 'egérharapó', és a Salat, Zalat (uo.; 1765: ua. 'Cyprinus afpius' [Icht.Bor. 47], 1863: Am Kurischen Haff Salat [Siebold 170], 1911: Zalat 'Rapfen' [Brockhaus 2: 1013]), amely átkerült más nyelvbe is; vö. lett salate, litv. salatis 'ua.' (FB.). Földrajzi nevekkel honosságra utal ném. kaspischer Rapfen és ang. Aral asp (uo.), azaz 'Kaszpi-, illetve Aral-tavi őn'.

Az őn régi neve a ném. Schied, nyelvjárási schiegg, schiek, schier, schirm, schütt (FB.; 1682: Schied [Hohberg 2: 17], 1792: ua. [Bechftein 769], 1793: Ausztria: Schied 'Cyprinus afpius' [Allg.Pol-Lex. 1: 1355], 1798: ua. [Adelung 3: 1442], 1863: ua. [Siebold 169], 1864: In Bayern Schied [Jäckel 62], 1869: Schied, Schiedling 'Aspius rapax' [Brehm 5: 667], 1909: Schied 'ua.' [Meyers 17: 751], 1911: ua. [Brockhaus 2: 628]) és Jentling (1790: ua. 'Cyprinus rapax' [HbDT. 164]) társneve. Idegen nyelvi neve még a szerb буц̧ов, hv. buсоv, albuk, bajn (W.), kirgiz кадимки кой бальк, észt

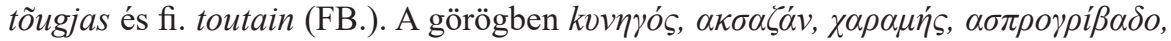
$\alpha \sigma \pi \rho o ́ \psi \alpha \rho o$ (uo.), a románban avat (W.; 1909: avat'Aspius rapax' [Antipa 169]), illetve haut (FB.; 1909: havat, havut 'Aspius rapax' [Antipa 169], Munténiában vrespere (uo.), aun, butoi, gonaci, guran, vâlcan, vâgan, vâlsan boulean, peşte țigânecs (FB.) néven ismerik. Társneve az or. falk (1793: ua. [Allg.Pol.-Lex. 1: 1356]), valamint az etimológiailag összetartozó or. жерех (FB.), fehéror. жэрах, csuv. шерегк (W.) és a kazah ақмарқ̧а, tatár агарчак (uo.).

Igen régről adatolható neve a németben a Rapfen, nyelvjárási raape, raapf, rapen (FB.; 1558: rappe [Hist.An. 1267], 1575: ua. [Fischb. 170a], 1603: Rappe 'Rapax' [Schwenckfeld 423], 1613: ua. [Aldrovandi 604], 1624: Rapen [Icht.Nom. 30], 1639: ua. [Micraelius 6: 384], 1670: ua. 'Rapax' [Gesnerus red. 4: 173], 1731: Rape 'Raubfisch' [Cur.-Lex. 1641], 1754: Rapen [Richter 889], 1782: Rapfen [Bloch 1: 48], 1790: Raapfe, Rape 'Cyprinus rapax' (HbDT. 164), 1792: Raapfen, Rappe [Bechftein 769], 1793: Raapfe, Raapfen, Rappe, Raape, Rapen, Rappfifch 'Cyprinus afpius' [Allg.Pol-Lex. 1: 1355], 1798: Rappe, Raapfen 'Aspius' [Donndorff 740], 1833: Rappe [Gloger 75], 1837: Raapfen [Bujack 337], 1839: ua. 'Cyprinus aspius' [Gmelin 369], 1840: Rapfen [Reichenbach 83], 1863: ua. 'Aspius rapax' [Siebold 169], 1884: ua. [BrehmsT. 8/2: 288]), amely az óporosz rapis 'ua.' (FB.) névre vezethetô vissza. 


\section{HIVATKOZÁSOK}

Adelung = Johann C. Adelung: Grammatisch-kritisches Wörterbuch der Hochdeutschen Mundart. Leipzig, 1793-1801.

ÁKE. = Munkácsi Bernát: Árja és kaukázusi elemek a finn-magyar nyelvekben. Budapest, 1901.

Aldrovandi $=$ Ulyssis Aldrovandi ... De piscibus libri V et De cetis lib. unus. Bononiae, 1613.

Allg.Pol.-Lex. = Philipp Andreas Nemnich: Allgemeines Polyglotten-Lexicon der NaturGeschichte. Hamburg, 1793-1798.

ÁM. = Háromnyelvü fejtö állatnév müszótár. Pest, 1846.

Antipa = Grigore Antipa: Fauna ichtiologică a româniei. Bucuresti, 1909. https://doi. org/10.5962/bhl.title. 64333

Ausf.B. = Johann Christoph von Pachelbel-Gehag: Ausführliche Beschreibung des FichtelBerges. Leipzig, 1716.

Bausch = Manfred Bausch: Die russischen Fischnamen . Berlin, 1965.

Bechftein = Johann M. Bechftein: Kurзgefa/3te gemeinnüzige Thiergefchichte des In- und Auslandes. Leipzig, 1792-.

Bielz = A. Bielz: Fauna der Wirbeltiere Siebenbürgens. Hermannstadt, 1856.

Bloch $=$ Marcus Elieser Bloch: Oeconomische Naturgeschichte der Fische Deutschlands. Berlin, 1782-1795. https://doi.org/10.5962/bhl.title.105191

Brehm $=$ Alfred E. Brehm: Illustrirtes Thierleben . Hildburghausen, Leipzig, 1864-1876. 4. Aufl. 1911-1920.

BrehmL. = Brehm Alfréd: Az állatok világa. 14. köt. Halak. A hazai viszonyokra alk. Leidenfrost Gyula. Budapest, 1930.

BrehmsT. $=$ Brehms Tierleben. Allgemeine Kunde des Tierreichs. Leipzig, 2. Afl. 1876-1879; kol. Aufl. 1882-1884. https://doi.org/10.5962/bhl.title.22893

Brockhaus = Brockhaus' kleines Konversations-Lexikon, 5. Aufl. Leipzig, 1911.

Bujack = Johann Gottlieb Bujack: Naturgeschichte der höheren Thiere mit besonderer ... Königsberg, 1837.

Chyzer = Chyzer Kornél: Zemplénmegye halai . Igló, 1882.

Com:Jan. = Johann Amos Comenii Janua linguae latinae. Leutschoviae, 1643. Kolozsvár, 1673.

Cur.-Lex. = Johann Hübner: Curieuses und Reales Natur-Kunft-Berg-Gewerck- und Handlungs-Lexicon. Hamburg, 1731.

Dankó = Dankó Imre: Bodrogközi halászszótár. A miskolci Herman Ottó Múzeum Évk. XI: 449-504. 1972.

Dankowsky $=$ Dankowsky Gregor: Magyaricae linguae lexicon . Posoni, 1833.

DEWOS = Wolfgang Steinitz: Dialektologisches und etymologisches Wörterbuch der ostjakischen Sprache. Berlin, 1966-.

DLw. = Lumtzer-Melich: Deutsche Ortsnamen und Lehnwörter. Innsbruck, 1900.

Donndorff = Zoologi (che beyträge zur XIII. Ausgabe des Linneifchen Naturfyftems von Johann August Donndorff. III. Leipzig, 1798.

Dugonics $=$ Dugonics András: Etelka. I-II. Posony, Pest, 1791.

EEWb. = Estnisches etymologisches Wörterbuch. Helsinki, 1983.

EL. = Encyclopedia of life. (A legnagyobb biológiai adatbázis) http://www.eol.org.

Estor $=$ Johann Georg Estor: Bürgerliche rechtsgelehrsamkeit der Teutschen. Bd. 1. Marburg, 1757.

FB. = Fischbase. A global species database of fish species. www.fishbase.org/search.php (hozzáférés: 2017. okt.). 
Ferianc = Oskár Ferianc: Slovenské názvoslovie ryb Československej republiky ... Turčiansky Svätý Martin, 1948.

Fischb. = Conrad Gesner: Fischbuch, das ist ein kurze, doch vollkommne Beschreybung aller Fischn ... Zurich, 1575; Franckfurt am Meyn, 1598.

Földr.Közl. = Földrajzi Közlemények. Budapest. 1873-1948. 1953 -.

FUF. = Finnisch-ugrische Forschungen. Helsinki, 1914-.

FUV. $=$ Björn Collinder: Fenno-Ugric Vocabulary. Hamburg, 1977.

Ges.Med. = Conradi Gesneri medici Tigurini Historiae animalium liber IV: qui est De piscium ... Francofurti, 1604.

Gesnerus red. $=$ C. Gessner - C. Forer - G. Horst: Gesnerus redivivus auctus \& emendatus. Vol. 4. Frankfurt a. M., 1670.

Gloger $=$ Constantin Wilhelm Lambert Gloger: Schlesiens Wirbelthier-Fauna. Breslau, 1833.

Gmelin = Carl Christian Gmelin: Gemeinnützige systematische Naturgeschichte der Fische . Mannheim, 1839.

Grossinger $=$ Joanne Bapt. Grossinger: Universa historia physica regni Hungariae. Posonii et Comaromii, 1794-1797.

Gyurkó = Gyurkó István: Édesvízi halaink. Bukarest, 1972.

Hal. = Halászat . Budapest, 1932-.

Halh. = Pintér Károly: Halhatározó. Budapest, 1989.

HalK. = Herman Ottó: A magyar halászat könyve I-II. Budapest, 1887.

HbDT. $=$ Handbuch der deutschen Thiergeschichte für Schulen. Gießen, 1790.

Heck. = Jacob Heckel: Magyarország halainak rendszeres átnézete. (Magyar Orvosok és Természetvizsgálók VIII. nagygyülésének évkönyve), 1863.

Hist.An. = Conradi Gesneri ... Historice Animalium Liber IIII. qui est de Piscium [et] Aquatilium ... Zürich, 1558.

Hist.Pisc. = Francis Willughby: De Historia piscium libri quatuor ... Oxford, 1686.

Hohberg = Wolf Helmhard von Hohberg: Georgica Curiosa. Bd. 2. Nürnberg, 1682.

Hunfalvy = Hunfalvy János: A magyar birodalom. III. Pest, 1865.

Icht.Bor. = Johan. Christoph. Wulff: Ichthyologia cum Amphibiis regni Borussici. Regiomonti, 1765.

Icht.Nom. $=$ Stephanus Schonevelde: Ichthyologia et Nomenclaturae animalium marinorum, fluviatilium ... Hamburgi, 1624.

Jäckel = Andreas J. Jäckel: Die Fische Bayerns. Abh. des zool.-miner. Vereines in Regensburg. 9. 1864.

Jankó = Jankó János: A Balaton-melléki lakosság néprajza. Budapest, 1902.

Kassai = Kassai József: Származtató, ’’ gyökerészö magyar-diák szó-könyv. I-IV. Pestenn, $1833-1838$.

Kovács = Kovács Antal: A halászat szakszókincse a Felsö-Szigetközben. Budapest, 1987.

Kriesch = Kriesch János: Halaink és haltenyésztésünk. Pest, 1868.

Mäger = Mart Mäger: Juhend ja nimastik kalanimetuste kogumiseks. Tallinn, 1973.

Landgráf = Landgráf János: Halászat. Magyarország közgazdasági és közmüvelődési állapota. 6. Budapest, 1897.

Meyers $=$ Meyers großes Konversations-Lexikon. Ein Nachschlagewerk des allgemeinen Wissens. Leipzig, 1902-1908/1920.

Micraelius = Johann Micraelius: Sechstes vnd Letztes Buch Von deß Pommerlandes Gelegenheit ... Stettin, 1639.

MoH. = Pintér Károly: Magyarország halai . Budapest, 1989.

Müller = Philipp L. Statius Müller: Des Ritters Carl von Linné ... vollftändiges Naturfyftem ... 4. Fifche. Nưrnberg, 1774. 
$\mathrm{Nau}=$ Bernhard S. von Nau: Oekonomische Naturgeschichte der Fische in der Gegend um Mainz. Mainz, 1787.

Никольский = Георгий Васильевич Никольский: Частная ихтиология. Москва, 1950.

Pellegrin = Jacques Pellegrin: Le lac Balaton et sa fauna ichtyologique. La Terre et la Vie 329-335. 1931 Juillet.

Prem.gimn. = Premontrei katolikus fögimnázium. Iskolai értesítő. Keszthely, 1904.

Reichenbach $=$ Anton Benedikt Reichenbach: Die Fi che: dargestellt in getreuen Abbildungen und mit ... Leipzig, 1840.

Reisinger = Joannes R. Reisinger: Specimen ichthyologiae. Buda, 1830.

REWb. = Max Vasmer: Russisches etymologisches Wörterbuch. Heidelberg, 1955.

RF. = Irmgard Leder: Russische Fischnamen. Wiebaden, 1971.

Richter $=$ Johann Gottfried Richter: Ichthyotheologie, oder: Vernunft- und Schriftmå $/ 3 i g e r$ Versuch... Leipzig, 1754.

RLw. = Béla Kálmán: Die russischen Lehnwörter im Wogulischen . Budapest, 1961.

Rössig = Carl Gottlob: Versuch einer pragmatischen Geschichte der Ökonomie- ... Bd. 2,1. Leipzig, 1782.

RSzK. = Recsnik szrpszkohrvatszkog knyizsevnog $i$ narodnog jezika . Beograd, 1959.

Schwenckfeld = Caspar Schwenckfeld: Therio-Tropheum Silefiae: in quo animalium ... Lignicii [Liegnitz], 1603.

Selys-Longchamps $=$ Michel-Edmond baron de Selys-Longchamps: Faune Belge. Liége, 1842. https://doi.org/10.5962/bhl.title.123627

Siebold $=$ Carl Theodor von Siebold: Die Süsswasserfische von Mitteleuropa . Leipzig, 1863. https://doi.org/10.5962/bhl.title.61814

SKES. = Suomen kielen etymologinen sanakirja. Helsinki, 1955-.

SNPol. = Erazm Majewski: Stownik nazwisk zoologicznych i botanicznych polskich. I-II. Warsawa, 1889-1894.

Syst.Nat. = Caroli Linnaei...Systema naturae per regna tria naturae: secundum classes, ordines ... Holmiæ, 1758-1759.

Term.Hist. $=$ Földi János: Természeti história . Pozson, 1801.

Term.Tud.Közl. = Természettudományi Közlöny. Budapest, 1869-1944.

Tiles = Tiles Nándor: A Balaton halainak népies elnevezése. A Bakonyi Múz. Népr. Adattára, kézirat. Veszprém.

Tud.Gyüjt. = Tudományos Gyüjtemény. Pest, 1817-1841.

Unger = Unger Emil: Magyar édesvizi halhatározó. Budapest, 1919.

Univ.Lex. = Pierer's Universal-Lexikon der Vergangenheit und Gegenwart. 4. Auflage. Altenburg, 1857-1865.

Vadl. $=$ Vadász Lap [Vadászlap]. Pest, Budapest, 1879-1920.

Viski = Viski Károly: Tihany öshalászata (NéprÉrt. 1932: 37-54).

Владыков = Вадим Владыков: Обычные названия рыб в различных местностях Подкарпатской Руси. Просвите, 5: 205-232. Ужгород, 1927.

VN. = Gozmány László: Vocabularium nominum animalium Europae septem linguis red. $\mathrm{Bu}-$ dapest, 1979.

Vutskits = Vutskits György: A Magyar Birodalom halrajzi vázlata. Keszthely, 1904.

$\mathrm{W}$. . Wikipedia, the free encyclopedia (http://...wikipedia.org).

Wog.Wb. = Béla Kálmán: Wogulisches Wörterbuch. Budapest, 1986.

ZSIPh. = Zeitschrift für slavische Philologie. Leipzig-Heidelberg, 1924-.

Zoogr.R. = Peter S. Pallas: Zoographia Rosso-Asiatica: sistens omnium animalium in extenso Imperio Rossico. Petropoli, 1831. 